\title{
Type studies in Russula 1: on two species described by Kühner
}

\author{
JUHANI RUOTSALAINEN and SEPPO HUHTINEN
}

\begin{abstract}
RUOTSALAINEN, J. \& HUHTINEN, S. 2015 (2016): Type studies in Russula 1: on two species described by Kühner - Karstenia 55: 61-68. HELSINKI. ISSN 0453-3402.

Based on a detailed study of holotypes, emended descriptions of two somewhat problematic species are given. Recent material of those taxa is also presented with colour photographs. Russula nuoljae and $R$. purpureofusca were both described by Kühner based on one or two fruitbodies collected from Scandinavian fjelds. $R$. cupreola is shown to be synonymous with $R$. purpureofusca.
\end{abstract}

Key words: Agaricales, Russula, Kühner, montane, arctic-alpine mycology, Fennoscandia

Juhani Ruotsalainen, Metsärinne 12 A 4, FI-71310 Vehmersalmi, Finland; e-mail: juhani.ruotsalainen@pp.inet.fi

Seppo Huhtinen, Herbarium, University of Turku, FI-20014 Turku, Finland; e-mail: sephuh@utu.fi

\section{Introduction}

Russula Pers. is a large and difficult genus. Relatively variable characters are used in species delimitation. This places special requirements for type specimens. Contradictory to that, numerous taxa are based on scanty, juvenile or mixed type specimens, even though they are not very old taxa. In this series of articles we will offer detailed observations of such specimens to help future studies. For instance, in 1975 Kühner described five new species and two new varieties of alpine/montane Russulas. Four of these were based partly or totally on Scandinavian material (Kühner 1975). The new taxa were described without any pictures or microscopic drawings. Combined with the fact that Kühner's herbarium was practically not available before it was annexed to Geneve, it is not surprising that unanimous circumscription of these taxa was not reached. They have been included in some papers (Romagnesi 1985, Bon 1988, Sarnari
1998, 2005, Adamcík 2004, Adamcík \& Knudsen 2004, Ronikier 2008, Knudsen et al. 2012) but the way they were described and the scarce original material have made interpretations difficult. Hence, fresh material collected in northern Fennoscandia has been difficult to name. The four species and their subsequent subsections were: $R$. pseudocampestris Kühner (Integrinae), $R$. heterochroa Kühner, $R$. purpureofusca Kühner (Tenellae), R. nuoljae Kühner (Viridantinae). In this paper we present detailed drawings of microscopical features of the two last-mentioned, as well as informative colour photos of recent specimens.

\section{Material and methods}

The specimens were studied with Leitz Laborlux 10 and characters drawn using a drawing apparatus. Spores were 


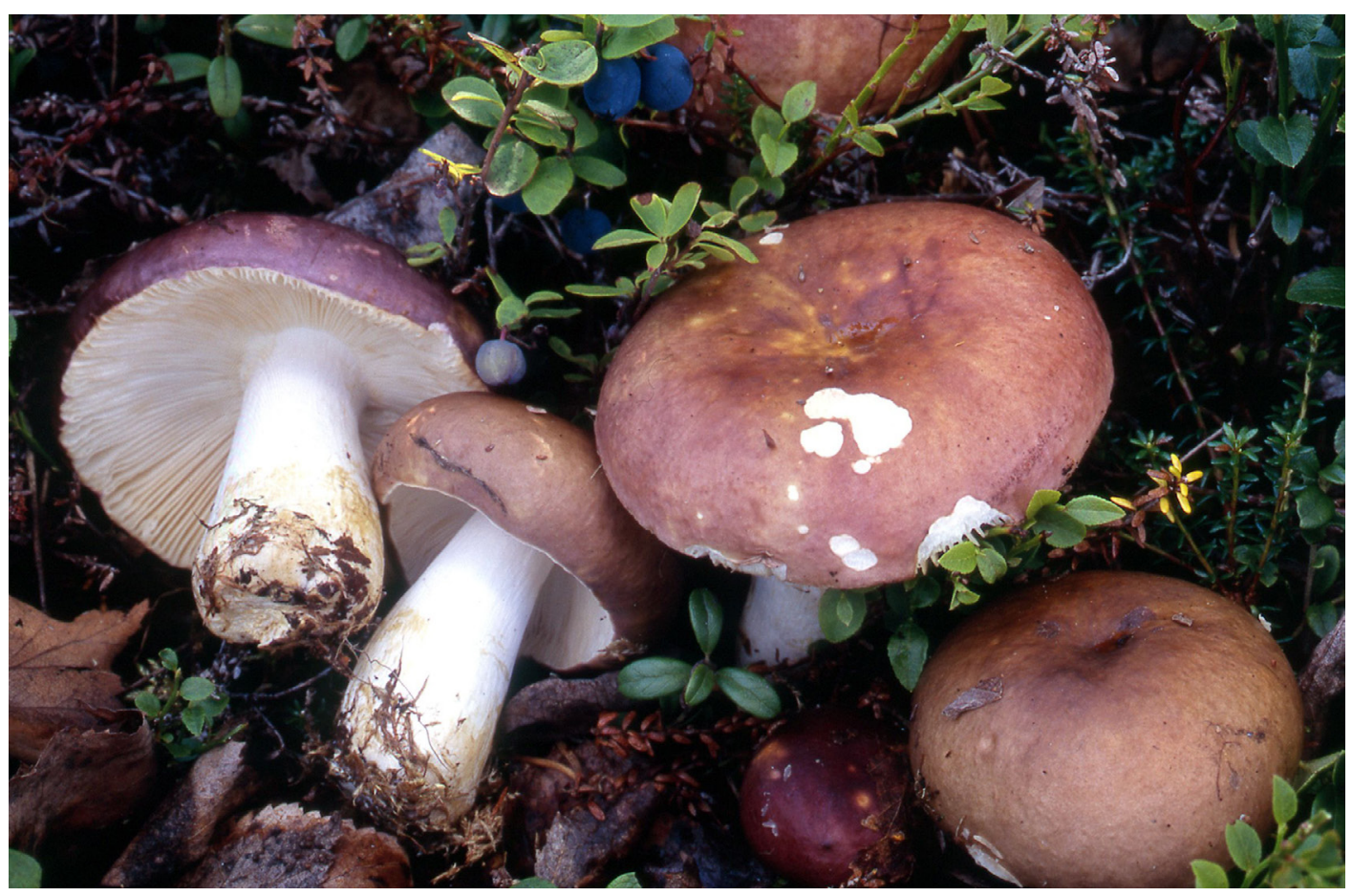

Fig. 1. Russula nuoljae, Ruotsalainen JR.6612F. - Photo: J. Ruotsalainen.

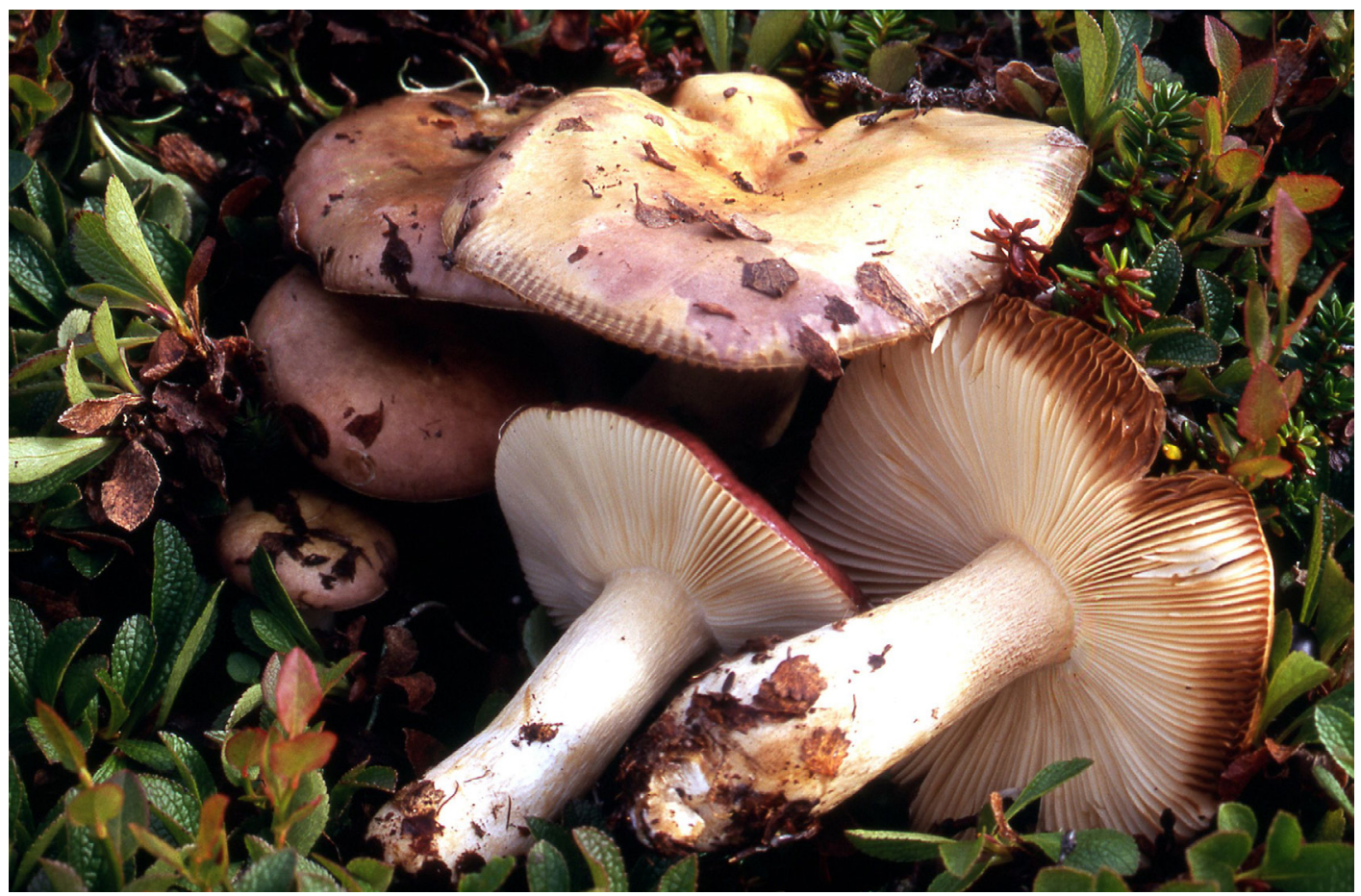

Fig. 2. Russula nuoljae, same population with older fruitbodies .- Photo: J. Ruotsalainen. 
observed in Melzer's Reagent (using $\times 1250$ magnification). Preparations were made from gills (from types), from recent collections spores were illustrated both from spore prints and gill preparations. Elements of the cap cuticle were studied in water, using $\times 800$ magnification. They are illustrated from preparations made in water.

\section{Russula nuoljae Kühner, Bull. Soc. Mycol.} Fr. 91: 388. 1973 - Figs. 1-4

The Latin diagnosis is relatively short and is based on a single fruitbody: "Pileo $57 \mathrm{~mm}$, purpureo; stipite haud purpureo; massa sporarum pallide ochracea. Sporis 7.7-9.2 × 6.5-7.5 $\mu$, verrucis fere omnibus singularibus. Pleurocystidiis permultis, sulfopiperonalis ope nigrescentipus. Species praesertim insignis carentia dermatocystidiorum. - In zona alpina Lapponica. - Typus: Herb. Kühner n 67.129."

The species was placed in subsection Viridantinae by Kühner. Although he gives additional characters in the description, it has been problematic to affiliate the name to modern collections, because the sole fruitbody in the type collection is somewhat juvenile. Hence, cap colour and the colour of spore print have not been straightforwardly applied to newer collections. The taste, which is rather soon somewhat acrid, was not mentioned by Kühner either. The number of spores in the holotype is scarce, indicating a juvenile fruitbody, as well as the larger fruitbodies (80-110 $\mathrm{mm}$ in diam) frequently met. Especially problematic young specimens are in alpine material, where the "true" ornamentation and spore-print colour would need a type collection containing truly mature fruitbodies (cf. Fig $\mathrm{x}$ ). The colour of spore-print was given as deep ochre (ocre clair) In our material it shows some variability (as often in alpine collections): Romagnesi IId - IIIa(-b), Dagron 8-9(-10). Spores in recent material have been found out to be slightly bigger than those seen by Kühner. It is unclear whether Kühner studied the spores from gills or from a spore print. In our material spores measure 8-9.5 × 7.2-7.8 $\mu \mathrm{m}(\mathrm{n}=50$, from 12 populations). Comparing spores in gill preparation and in spore-prints one can verify that Kühner's type is a juvenile fruitbody. In the type the spores have a somewhat deviating ornamentation; warts are smaller and with more connectives (Fig x, holotype; Fig x, lowermost spore) than in mature spores.

The larger material has shown some variabil- ity in cap colour (Figs. 1, 2) within and between populations. Olivaceous caps were not seen in our material. Hence, we do not support the synonymy suggested by Adamcík (2004) and Adamcík \& Knudsen (2004). Based on a study of the type of $R$. nuoljae, they concluded that Kühner's species could be a synonym of $R$. clavipes Velen., a predominantly olivaceous-capped species. The clear difference in cap colour of $R$. nuoljae was suggested to be due to longer exposure to sun (Adamcík 2004). Based on our wider observations, we treat $R$. nuoljae as a separate species. In addition, the stipe is always white; reddish colour has not been observed in the field in the 12 studied populations (mentioned as a common feature by Adamcík 2004).

Kühner collected the specimen amongst $\mathrm{Sa}$ lix reticulata and Betula nana at fjeld Nuolja at Abisko (North Sweden). Newer collections indicate that the species is relatively easy to find from alpine heaths e.g. near Kilpisjärvi, growing with dwarf Salix spp. and with Betula pubesces var. czerepanovii and B. nana. It is also found at lower level mountain birch forests.

Specimens examined: FINLAND. Enontekiön Lappi. Enontekiö, Kilpisjärvi, Goallarrássa, E-slope, alt. ca 600 m., with Betula and Salix, 11.VIII.1986 Metsänheimo \& Ruotsalainen JR.295F (KUO); Kilpisjärvi, Malla Strict Nature Reserve, Pikku-Malla, SW-slope, alt. ca 600 m., 21.VIII.1995 Vauras \& Ruotsalainen JR.1743 (KUO); Kilpisjärvi, at the Biological Research Station, alt. ca 500 m., with Betula, 12.VIII.1990 Vauras \& Ruotsalainen JR.1757F (KUO); same site, 15.VIII.1990 Ruotsalainen JR.1809 (KUO); Kilpisjärvi, Jehkas, alt. ca 580 m., arctic heath with Salix reticulata and Betula nana, 16.VIII.2004 Vauras \& Ruotsalainen JR.6612F (KUO, TUR), 24.VIII.2014 Campo \& Ruotsalainen JR.9187, 24.VIII.2014 Ruotsalainen JR.9188, 22.VIII.2015 Kukkola \& Ruotsalainen JR.9322 (KUO). NORWAY. More og Romsdal. Nesset, alt. ca 800 m., 21.VIII.2004 Larsen 7-04, det. Ruotsalainen (O). Troms. Storfjord, Helligskogen, Rihpojávri 1 km W., alt. ca 700 m., arctic heath with Salix herbacea, S. reticulata and Dryas, 27.VIII.2015 Ruotsalainen JR.9358 (KUO). RUSSIA. Murmansk Oblast. Kirovsk, Lake Vudjaur, N-side, at tree line, alt. ca 470 m., with Juniperus communis, Salix cf. myrsnites, Betula nana, Betula pubescens, 16.VIII.2004 


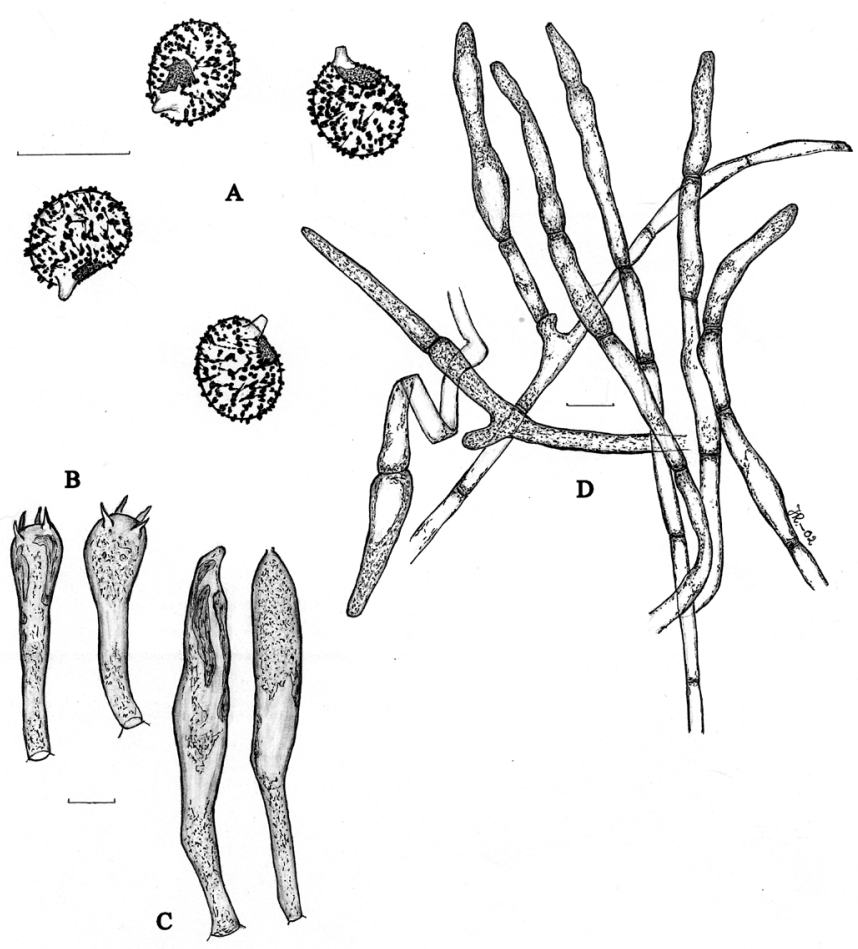

Fig. 3. Microscopical characters of Russula nuoljae, holotype. A = spores, $\mathrm{B}=$ basidia, $\mathrm{C}=$ pleurocystidia, $\mathrm{D}=$ pileocystidia. - Scales $=10 \mathrm{um}$.

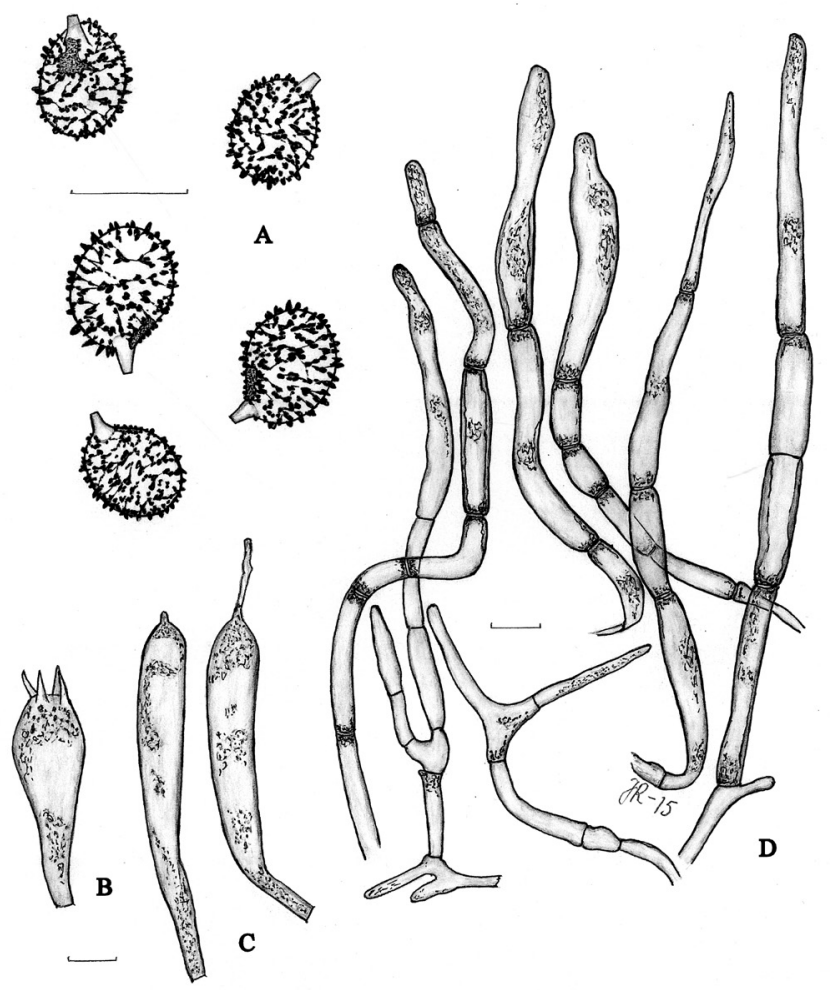

Fig. 4. Microscopical characters of Russula nuoljae, Ruotsalainen JR.6612F. A = spores, $\mathrm{B}=$ basidia, $\mathrm{C}$ = pleurocystidia, $\mathrm{D}=$ pileocystidia. Scales $=10 \mathrm{um}$. 


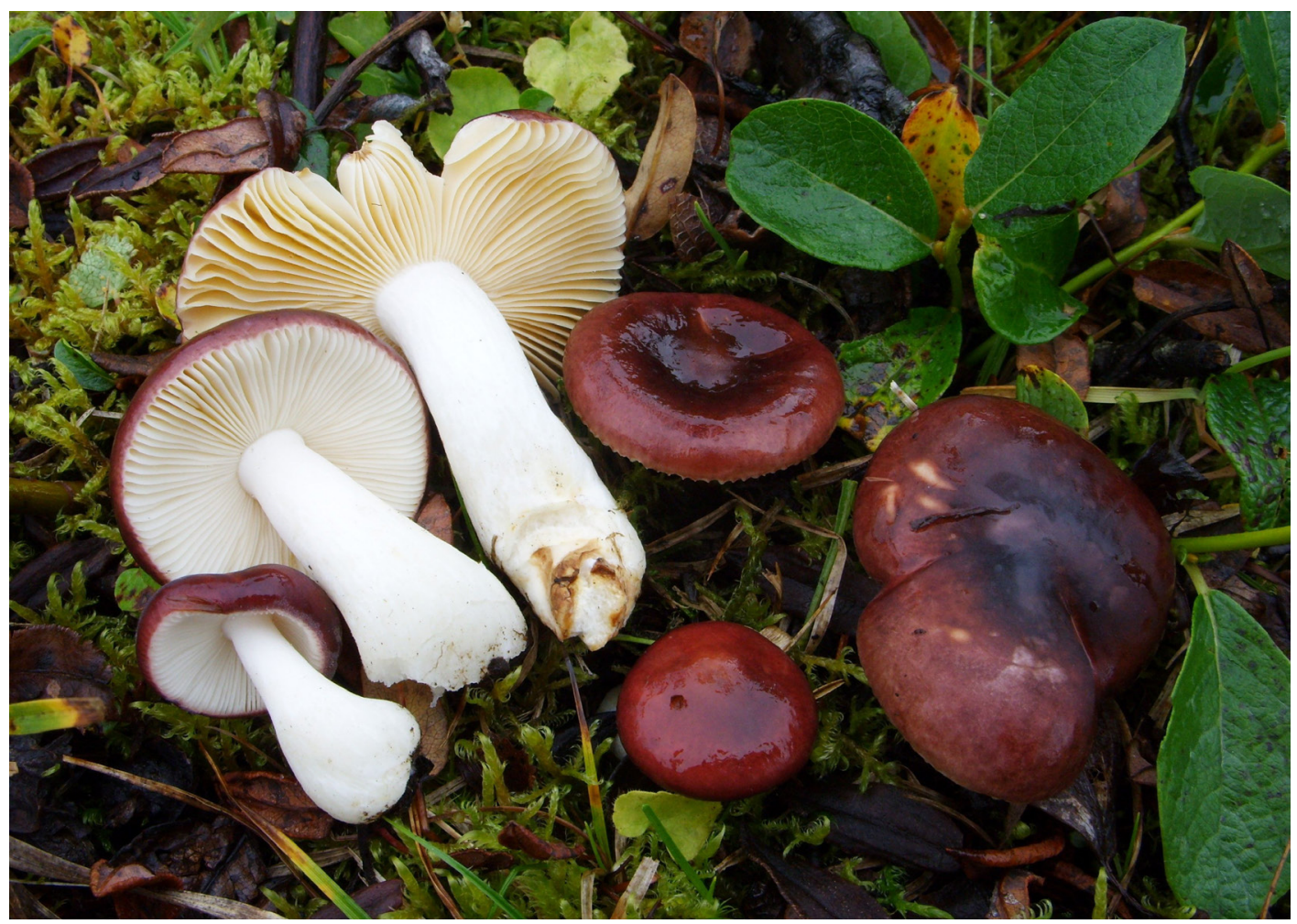

Fig. 5. Russula purpureofusca, Ruotsalainen JR.9032F. - Photo: J. Ruotsalainen.

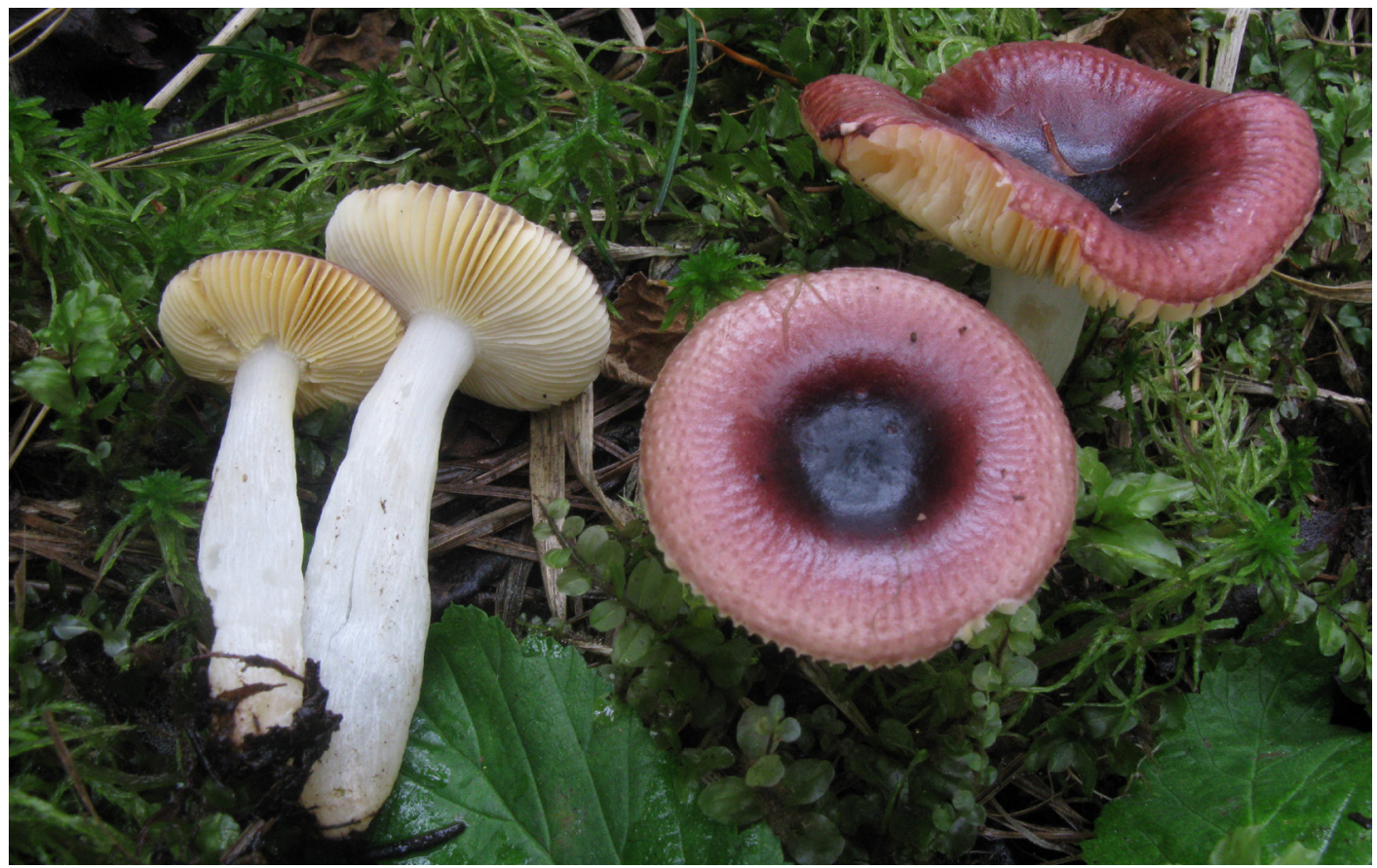

Fig. 6. Russula purpureofusca, Ruotsalainen JR.8195F. - Photo: J. Ruotsalainen. 
A.-L. Ruotsalainen, det. Ruotsalainen (OULU). SWEDEN. Jämtland. Undersåker, Renfjellet, close to the summit, alt. ca 900 m., with Betula and Salix reticulata. 25.VIII.2001 Vauras \& Ruotsalainen JR.5831 (KUO).

Russula purpureofusca Kühner, Bull. Soc. Mycol. Fr. 91: 389. 1973 - Figs. 5-8

= Russula cupreola Sarnari, Boll. Assoc. Micol. Ecol. Romana 7 (20-21): 64. 1990

The Latin diagnosis of $R$. purpureofusca is relatively short and is based on two fruitbodies: "Pileo 25-27 mm, sorde e rubro brunneo; stipite albo; odore acido; sapore acri; massa sporarum mediocriter cremea. Sporis 8-8.7 $\times 6.7-7.5 \mu$, punctis humilibus atque tenuibus, cum connexivis tam subtilibus ut facile neglegantur. Dermatocystidiis angustis, $3.5-6 \mu$, septatis. Pigmenta proxima sunt pigmentis R. norvegicae Reid et R. saliceticolae Singer, sed differunt praesentia russularhodinae II. - In zona alpina Norvegica. - Typus : Herb. Kühner n 72.60 ."

Kühner's species has remained a mystery, much due to the young fruitbodies in the type collection. From these he got a much too light spore print (Romagnesi IIc). Hence, collections from Fennoscandian mountains never seemed to match $R$. purpureofusca. Only after studying the holotype it became evident that material collected under the name $R$. cupreola could be Kühner's species. This was verified by studying the holotype of Sarnari's species: spores were identical in both holotypes and pileocystidia showed abundant lateral diverticulae. The main difference between the two holotypes lies in the width and septation of these elements, the type of $R$. cupreola showing the extremes in width and dense septation. Variability towards the other extreme (Kühner's type) was already included in Sarnari's (1990) plate illustrating pileipellis from three collections of $R$. cupreola.

The problem with the totally different spore print colours (given as IVc - IVd for the holotype of $R$. cupreola) was solved by observations from rich populations in the field. Young fruitbodies have almost pure white gills whereas in mature ones in the same collection they are clearly ochraceous (Fig. x). The variability in spore prints in our material is: from Romagnesi
IIIb - IIIc (Dagron 12-13) to IVb - IVc(-d) (Dagron $20-24)$. From young fruitbodies one can gain spore prints having the same colour Kühner reported.

Kühner (1973) did not notice the odour of Pelargonium which is mentioned for $R$. cupreola and is present in some of the alpine collections (Pelargonium to Rhododendron tomentosum). Two of the southernmost collections (cf. Fig. 6) from Finland (Kainuu) were sequenced (ITS1) and found to be conspecific with alpine collections. The type was collected amongst Salix reticulata and also the type of $R$. cupreola grew amongsts dwarf Salix species. Our material grew with various Salix species and many of the sites had also Betula spp.

Specimens examined: FINLAND. Kainuu. Paltamo, Tololanmäki, Kylmänpuro Nature Reserve, inundated brook margin, wooded mire, 16.VIII.2010 Vauras \& Ruotsalainen JR.8131F (KUO); same locality, 20.VIII.2010 Vauras \& Ruotsalainen JR.8195F (KUO); Saukkovaara, W-slope, tussock in a brooklet, 24.VIII.2011 Ruotsalainen JR.8445F (KUO); same locality, 17.VIII.2014 Vauras 30625F (TUR-A). Koillismaa. Kuusamo, Iivaara NE, eutrophic fen, 24.VIII.1992 Vauras, det. Ruotsalainen, JR.2738 (TUR-A). Perä-Pohjanmaa. Rovaniemi, Hautapäänoja, rich brookside, 05.IX.2013 Siuvatti, det. Ruotsalainen, JR.9083 (KUO); Ylitornio, Romppaat N, margin of a wooded mire, with Betula, Picea and Pinus, 03.IX.2013 Ruotsalainen JR.9057 (KUO). Enontekiön Lappi. Enontekiö, Kilpisjärvi, Goallarrássa, E-slope, alt. ca 750 m., with Salix reticulata, 11.VIII.1986 Metsänheimo \& Ruotsalainen JR.294c. (KUO); Kilpisjärvi, Malla Strict Nature Reserve, Pikku-Malla, NE-slope, 21.VIII.1995 Walleyn, Buyck, Vauras \& Ruotsalainen JR.4010 (H, sub. R. cupreola); Kilpisjärvi, Tšahkaljohka, alt. ca 500 m., brookside with Betula and Salix, 13.VIII.1990 Vauras \& Ruotsalainen JR.1772, JR.1774 (KUO); same site, 15.VIII.1990 Vauras \& Ruotsalainen JR.1796F (KUO, TUR-A), JR.1797F (KUO, TUR-A, sub. R. cupreola, det. Sarnari); Kilpisjärvi, Possovarri, Possojoki-river, alt. ca 550 m., with Betula and Salix, 14.VIII.1990 Ruotsalainen JR.1782 (KUO); Kilpisjärvi, Saana SWslope, alt. ca 530 m., 16.VIII.1990 Ruotsalainen JR.1829 (KUO). NORWAY. Sör-Tröndelag. Oppdal, Konsvold, alt. ca 900 m., alpine garden, 

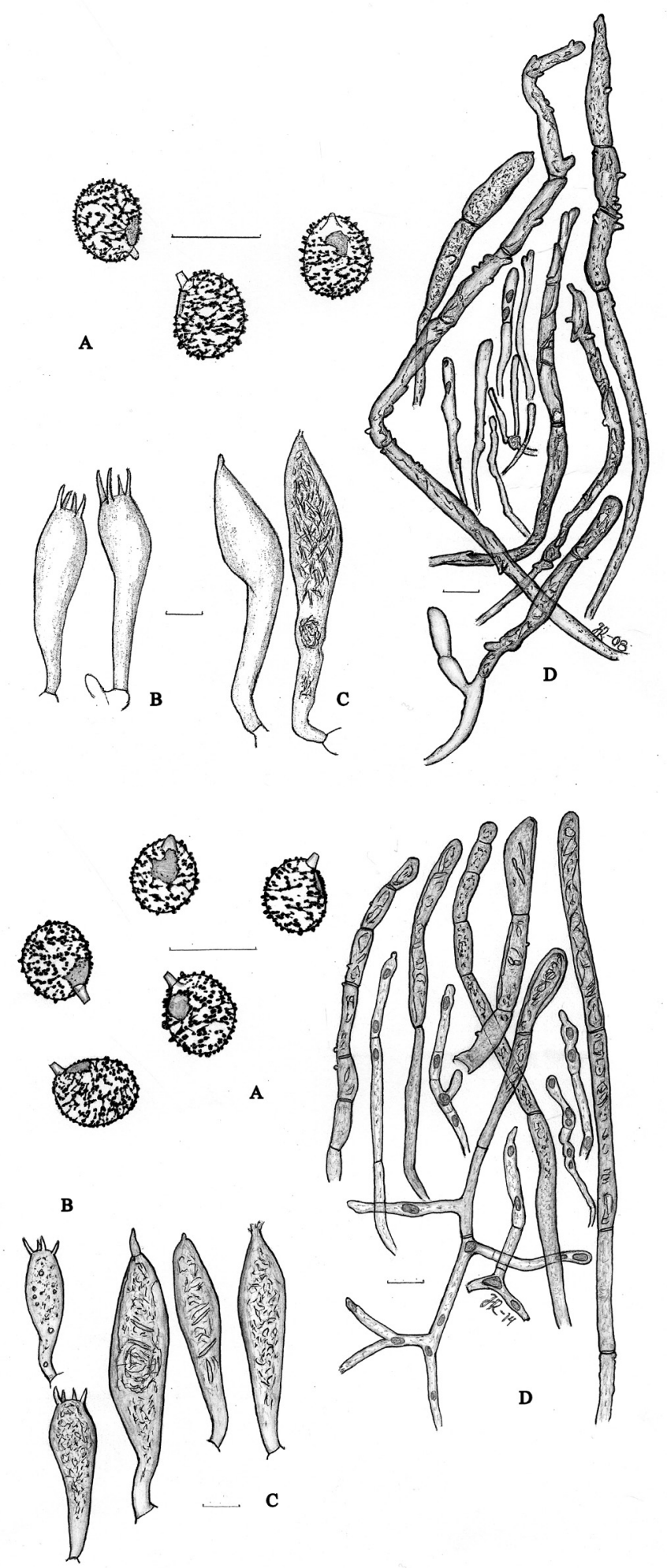

Fig. 7. Microscopical characters of Russula purpureofusca, holotype. A $=$ spores, $\mathrm{B}=$ basidia, $\mathrm{C}=$ pleurocystidia, $\mathrm{D}=$ pileocystidia. - Scales $=10$ um.

Fig. 8. Microscopical characters of Russula purpureofusca, Ruotsalainen JR. $9032 F . \mathrm{A}=$ spores, $\mathrm{B}=$ basidia, $\mathrm{C}$ = pleurocystidia, $\mathrm{D}=$ pileocystidia. Scales $=10$ um. 
with Salix, 8.VIII.1991 Vauras \& Ruotsalalainen JR.2241F, JR.2243 (KUO). Troms. Storfjord, Salluoaivi E-slope, alt. ca 850 m., with Salix reticulata, 22.VIII.1995 Walleyn, Buyck, Vauras \& Ruotsalainen JR.4028b (KUO); Tromsö, Fløya, alt. ca 500 m., with Salix herbacea, 30.IX.2013 Rämä \& Ruotsalainen JR.9032F, JR.9033F, JR.9034F (KUO); Storfjord, Paras, SW-slope, alt. ca 800 m., with Dryas octopetala, 12 . VIII.1986 Metsänheimo, Vauras \& Ruotsalainen JR.309 (KUO). SWITZERLAND. Ticino. Val Corno, with Salix herbacea, S. reticulata and $S$. retusa, 17.VIII.1990 Sarnari 1989/0550 (holotype of $R$. cupreola, IB)

\begin{abstract}
Acknowledgements: Jukka Vauras is thanked for collecting some of the specimens and for comments on the manuscript. Kare Liimatainen is thanked for verifying with ITS many collections of $R$. purpureofusca. Ernest Emmett is thanked for checking the English language. Finally, the senior author wants to thank Kuopion Luonnon Ystäväin Yhdistys (KLYY) for grants to study the genus Russula.
\end{abstract}

\section{Refrences}

Adamcík, S. 2004: Studies on Russula clavipes and related taxa of Russula section Xerampelinae with a predominantly olivaceous pileus. - Persoonia 18: 393-409.

Adamcík, S. \& Knudsen, H. 2004: Red-capped species of Russula sect. Xerampelinae associated with dwarf scrub. - Mycological Research 108: 1463-1475.

Bon, M. 1988: Clé Monographique des Russules d'Europe. - Documents Mycolologiques 70-71: $1-120$.

Knudsen, H., Ruotsalainen, J. \& Vauras, J. 2012: Russula Pers. - In: Knudsen, H. \& Vesterholt, J. (eds.). Funga Nordica. Agaricoid, boletoid, clavarioid, cyphelloid and gastroid genera: 144-186. Nordsvamp. Copenhagen.

Kühner, R. 1975: Agaricales de la zone alpine. Genre Russula Pers. ex S.F. Gray. - Bulletin de la Société Mycologique de France 91: 313-390.

Romagnesi, H. 1985: Russules d'Europe et d'Afrique du Nord. Bordas. Paris, 1085 pp.

Ronikier, A. 2008: Contribution to the biogeography of arctic-alpine fungi: first records in the Southern Carpathians (Romania). - Sommerfeldtia 31: 191-121.

Sarnari, M. 1990: Una nuova specie di Russula propria delle microsilve alpine. - Bollettino dell'Associazione Micologica ed Ecologica Romana 20-21: 60-65.

Sarnari, M. 1998: Monografia illustrata del Genere Russula in Europa, Vol 1. - Associazione Micologica Bresadola. Trento, $799 \mathrm{pp}$.

Sarnari, M. 2005: Monografia illustrata del Genere Russula in Europa, Vol 2. - Associazione Micologica Bresadola. Trento, $769 \mathrm{pp}$. 